\title{
Na noite nem todos os gatos são pardos Notas sobre a prostituição travesti*
}

\author{
Larissa Pelúcio**
}

\begin{abstract}
Resumo
Esse artigo propõe uma discussão sobre a prostituição travesti, procurando evidenciar a importância dos territórios de prostituição como locais fundamentais para a construção do "ser travesti". Através das diferentes categorias êmicas que classificam as travestis, sobretudo, no comércio sexual, é possível perceber a relação das travestis com os clientes. A violência das ruas, o uso de drogas, o sonho e a realidade da prostituição na Itália, temas abordados nessa análise, são atravessados pelos afetos, disputas, demarcações territoriais e o sentido das relações afetivas e comerciais.
\end{abstract}

Palavras-chave: Travestis, Prostituição, Clientes, Gênero, Sexualidade.

\footnotetext{
* Recebido para publicação em agosto de 2005, aprovado em outubro de 2005.

** Doutoranda em Ciências Sociais, Universidade Federal de São Carlos, São Carlos-SP. larissapelucio@ yahoo.com.br
} 
Na noite nem todos os gatos são pardos

At Night, not All Cats are G ray:

Notes on Transvestite Prostitution

\begin{abstract}
In this article transvestite's prostitution is discussed trying to evidence the importance of the prostitution territories as fundamental places for the construction of the "transvestite self". The article also discusses different emic categories that classify the transvestites, especially in the sexual trade, bringing to the discussion the relationship of transvestites with their clientele. The violence of the streets, the use of drugs, the dream and the reality of prostitution in Italy also have room in this work crossed by the affections, disputes, territorial demarcations and the sense of the affective and commercial relationships that involve the transvestite universe.
\end{abstract}

Key Words: Transvestites, Prostitution, Customers, Gender, Sexuality. 
Larissa Pelúcio

Trilhas da noite

Há um pouco mais de dois anos iniciei meu trabalho etnográfico junto às travestis. Abri o campo a partir dos espaços de lazer freqüentados por esse público na cidade de São Carlos, interior paulista. Aqui, como em outras localidades, mas talvez de maneira mais acentuada do que nos grandes centros, existe uma rede de sociabilidade que integra travestis e gays. ${ }^{1}$ Assim, em julho de 2003, cheguei à boate GLS (gays lésbicas e simpatizantes) recém inaugurada em São Carlos. 0 objetivo era colher dados para minha tese de doutorado que versa sobre o modelo oficial preventivo em HIV/aids aplicado ao grupo de travestis que se prostituem. A partir da perspectiva da Antropologia da saúde, eu buscava captar, entre elas, a formulação/circulação das informações preventivas em relação (1) à constituição das próprias redes de circulação das informações dentre este grupo; (2) às categorias locais que dizem respeito à sexualidade/corpo/doença, articuladas ao conjunto maior de valores que lhes orientam 0 comportamento; (3) ao modo como o discurso do modelo preventivo circula na comunidade e qual a lógica que preside esse processo, do ponto de vista do ethos diferenciado desta clientela.

No convívio com as travestis percebi que para responder às questões que me colocava era necessário me aproximar dos clientes delas. Caso contrário, teria uma visão parcial da realidade, afinal, trata-se de uma relação.

A partir desse insight, a questão era como me aproximar desses homens? Mais uma vez a "luz" veio do próprio campo. J ennifer, travesti de São Carlos, me pediu fotos para o MSN, sistema on line de comunicação em tempo real. Comentei com ela que eu também usava o sistema e se poderia anexá-la, no que ela concordou. Logo me ocorreu que ela deveria usar o sistema para

\footnotetext{
${ }^{1}$ Entendidos aqui como rapazes com práticas homoeróticas e orientação sexual auto-reconhecida como homossexual, que pautam o seu consumo por um determinado conjunto de valores que os identifica entre si e que angariam um certo capital cultural e social que os filia às classes média e média baixa.
} 
Na noite nem todos os gatos são pardos

conversas com homens. Confirmei minhas suspeitas e perguntei a ela onde ela conseguia os contatos de e-mail desses homens. Sua resposta - "Pelos chats, nas salas gays" - abriu o caminho de aproximação que eu procurava. Marcamos diversas vezes de entrar juntas nas salas de bate-papo, mas por um motivo ou outro isso nunca era possível, e eu não queria entrar fingindo ser uma travesti. Achei que não seria ético, além do que talvez fosse facilmente desmascarada, por não dominar as gírias do meio, entre outros traços de comportamento.

Nesse intervalo de tempo recebi um convite para ingressar na plataforma de sociabilidade virtual chamada Orkut, o que facilitou minha aproximação dos homens que gostam de fazer sexo com as travestis. Através dos espaços on-line cheguei ao offline $^{2}$, travando a interação com um grupo específico - os auto intitulados t-lovers. ${ }^{3}$ Nos seus encontros semanais conheci travestis

2 Utilizo os pares on line/off-line, no lugar de virtual/real, me valendo da discussão feita por alguns autores que estudam essa área na Antropologia. Segundo esses autores, o par de virtual/real coloca em oposição esses termos, e o que se constata é que as interações ocorridas no universo dito virtual são bastante reais e, muitas vezes, se pautam na sociabilidade off-line e vice-versa. Considerando ainda que ambos os espaços se influenciam, convivem e pautam a sociabilidade que se desenvolve em cada um deles. Não são, portanto, compartimentados, mas imbricados. Ver GuIMARÃES, J r. M. J . L. Sociabilidade no Ciberespaço: Distinção entre Plataformas e Ambientes. http://www.cfh.ufsc.br/ guima/papers/plat_amb.html. Trabalho apresentado na $51^{\text {a }}$ Reunião Anual da SBPC - PUC/RS, julho de 1999, consulta em 07/03/2005; THOMSEN, S R.; StraubhaAR, J. D. BOLYARD, D. M. Ethnomethodology and the study of online communities: exploring the cyber streets. http://informationr.net/ir/41/paper50.html, consulta em 08/03/2005; DORNELLES, J. Antro pologia e Internet: quando o "campo" é a cidade e o computador é a "rede". Horizontes Antropológicos [online], vol. 10, № 21, jan./junho 2004, p.241-271.

3 o termo t-lover chegou ao Brasil via rede mundial de computadores, nascido na onda dos movimentos identitários que ganharam força nos anos 80 , sobretudo depois do surgimento da aids. Segundo um dos t-lovers pioneiros, 0 carioca Alex J ungle, o termo derivou de t-girl, usado por algumas ONGs norteamericanas para se referirem a transgêneros. Assim, os homens que se relacionavam com as t-girls (tgs) eram, conseqüentemente, os t-lovers. Um de meus informantes t-lovers, que reside nos Estados Unidos, afirma que esse termo 
tops, "européias", as que fazem "pista" e atendem pelo celular e Internet. Nesse espaço também acompanhei mais de perto as interações entre os clientes e as travestis. 0 que tem me aproximado do mundo da noite e me permitido aceder às redes de significados que os sujeitos tecem em seu convívio e que oferecem coerência às suas experiências vividas.

Além da observação participante, realizei entrevistas semiestruturadas com alguns indivíduos escolhidos de acordo com alguns critérios: disponibilidade e desejo manifesto de conceder a entrevista; travestis em papel de destaque - cafetina ou bombadeira. Interessei-me também por ouvir histórias de vida daquelas que se tornaram tops e/ou "européias". As entrevistas têm sido feitas também com clientes, sobretudo aqueles que freqüentam o $\mathrm{Dia} \mathrm{T}^{4}$, um encontro voltado para homens que saem com travestis. Com alguns mantenho estreito diálogo, proporcionado pela Internet, colhendo por esse canal muitos dados. Utilizo esse meio também com as travestis, sobretudo com aquelas que estão na Europa, o que me permite ter sempre informações novas sobre o grupo.

A partir dessas trilhas, esse artigo busca evidenciar a importância dos territórios de prostituição como locais

é pouco usado e vincula-se estreitamente ao universo homossexual. No Brasil, os t-lovers estão fortemente id entificados com a heteronormatividade, trabalham e reforçam a masculinidade enquanto valor simbólico, associando-a sempre à "normalidade", em oposição à homossexualidade, tida como "desvio". Considero como t-lovers apenas os grupos restritos que vem se organizando em várias grandes cidades do país e do exterior em torno de encontros off-line e fóruns de debate via Internet.

4 Este encontro acontece em algumas capitais do Brasil, acompanho o da capital paulista, que se realiza todas às quintas e sextas-feiras, em um "botecão" da tradicional "boca-do-lixo", área de prostituição no centro da cidade. 0 encontro começou a se articulado via sites, fóruns e blogs especializados na Internet e busca reunir homens que gostam de fazer sexo com travestis em reuniões nas quais possam falar livremente sobre o tema e encontrar travestis fora do ambiente da rua. 
Na noite nem todos os gatos são pardos

fundamentais para a construção da pessoa travesti. ${ }^{5}$ Nesse sentido, apresento as diferentes categorias êmicas usadas pelas travestis na classificação de si mesmas, sobretudo, no comércio sexual, trazendo para a discussão sua relação com os clientes, igualmente diferenciados pelas travestis, que acionam uma série de catego rias para elencá-los.

Ainda que reconheça convergências de comportamentos e visões de mundo semelhantes que conformam um ethos próprio desse grupo, enfatizo que a discussão aqui desenvolvida circunscreve-se ao universo do meu campo, no qual convivo com travestis que vivem e trabalham em São Carlos (cidade de médio porte do interior paulista) e de dois grupos de travestis paulistanas: as freqüentadoras do "Dia $T$ " e as agentes de prevenção do projeto "Tudo de Bom!" ${ }^{6}$, da prefeitura da capital. A violência das ruas, 0 uso de drogas, a aids, 0 sonho e a realidade da prostituição na Itália são temas abordados junto aos grupos pesquisados.

Nesse esforço de aproximação com 0 ambiente da prostituição travesti paulista deparei-me com os afetos, as

\footnotetext{
${ }^{5}$ Conceito usado aqui no sentido maussiano/dumountinano do termo. 0 que significa considerar que a pessoa se constitui a partir de um sistema moral e de valores próprios de cada sociedade e/ou grupo a que pertence. Desta forma, as culturas investem diretamente sobre os corpos, articulando os planos físico, psíquico e social, que assim imbricados, permitem que se considere os planos simbólico e o empírico como esferas articuladas, capazes de orientar todo um conjunto de práticas estruturadoras de experiência humana.

${ }^{6}$ O projeto preventivo em HIV/Aids "Tudo de Bom!" - alocado na agência pública de saúde DST/Aids Cidade de São Paulo, da Secretaria Municipal de Saúde - é voltado para trabalhadores do sexo que atuam na capital paulistana, valendo-se da "educação entre pares" como recurso metodológico de intervenção. Desta forma, profissionais de saúde ligados ao projeto "identificam nas regiões dos seus serviços pessoas que comercializam sexo, com perfil para 0 trabalho em campo. Estas pessoas, após formação espećfica, desenvolvem intervenções em áreas de prostituição da cidade". Ver ABATE, Ma Cristina. No Lugar da Tutela, o Diálogo e o Protagonismo. In: MesquiTA, F. e SouzA, C R de. DST/Aids a Nova Cara da Luta Contra a Epidemia na Cidade de São Paulo. São Paulo, Raiz da Terra, 2003, p.33.
} 
disputas, as demarcações territoriais e as relações amorosas e comerciais que compõem a sociabilidades que ali se estabelecem. Enfrentei olhares desconfiados e "saias justas", mas também fiz amizades sinceras e aprendi que há mais mitos sobre os perigos e desvarios da noite do que a realidade etnográfica aponta.

Dando "close" na avenida

Cena 1:

- Eu não sou puta! [Responde Verônica a Malu, orgulhosa de estar fora das ruas, ainda que viva da cafetinagem.]

Cena 2:

- Eu acho que tem valor quem faz programa. Não é muito mais fácil, eu que faço programa ter chance de conhecer alguém legal, ter uma pessoa do meu lado que possa me ajudar, entendeu, ou você que tá escondida? [Argumenta Sasha, travesti paulista, com Alessandra, recém-chegada do Rio de Janeiro, que está em dúvida se entra ou não para o mundo da prostituição.]

Cena 3:

- É como se fosse uma obrigação, nosso trabalho, tem que vir.

- Eu também. Se não venho sinto falta, é como se, sei lá... o dia não tivesse completo. [Conversam J ennifer e Fabyanna, enquanto rodamos de carro pela avenida G etúlio Vargas, ponto tradicional de prostituição travesti em São Carlos.]

A prostituição é entendida de diversas formas pelas travestis: (1) como uma atividade desprestigiosa, com a qual só se envolveriam por necessidade, saindo dela assim que possível; (2) como uma forma de ascender socialmente e ter conquistas materiais e simbólicas; (3) como um trabalho, sendo, portanto, geradora de renda e criadora de um ambiente de sociabilidade.

Essas não são posições estanques e definitivas, mas pontos de vista e percepções que se entrecruzam e dialogam. Como categoria espacial e simbólica - ligada à noite, à boemia, aos 
Na noite nem todos os gatos são pardos

prazeres e à prostituição -, a rua seduz. Para Duda Guimarães que atua na prestigiada avenida Indianópolis, em São Paulo, tradicional ponto de prostituição travesti -, "a esquina é o palco onde cada uma dá seu show". Na "avenida", categoria êmica para designar os espaços da prostituição rueira, elas testam o sucesso de seus esforços de transformação, "dando close" exibindo-se e esnobando as outras -, fazem amizades, aprendem a ser travesti a partir das trocas de informações e da observação. Nos territórios da prostituição elas namoram, encontram e fazem amigas, compram roupas, aprendem técnicas corporais importantes, além, é claro, de ganhar seu "aqué". ${ }^{7} \mathrm{Na}$ análise sensível de Benedetti,

É na convivência nos territórios de prostituição que as travestis incorporam os valores e formas do feminino, tomam conhecimento dos truques e técnicas do cotidiano da prostituição, conformam gostos e preferências (especialmente os sexuais) e muitas vezes ganham ou adotam um nome feminino. Este é um dos importantes espaços onde as travestis constroem-se corporal, subjetiva e socialmente. ${ }^{8}$

Na pele, na carne, na alma

"Ser travestis" é um processo, nunca se encerra. Construir um corpo e cuidá-lo é uma das maiores preocupações das travestis. Elas estão sempre buscando a "perfeição", o que significa "passar por mulher", uma mulher bonita e desejável, geralmente "branca" e burguesa. Em busca dessa imagem afinam seus traços, bronzeiam seus corpos, adornam-se com roupas de remetem a mulheres glamourosas, escolhem nomes de atrizes e

\footnotetext{
7 "Aqué" significa dinheiro. As travestis adotam uma série de termos vindos do io ruba-nagô, compondo uma espécie de gíria conhecida como bajubá, pajubá ou bate-bate, linguagem comum no Sul do Brasil.

8 BenedetTI, M. A batalha do corpo: breves reflexões sobre travestis e prostituição. www.ciudadaniasexual.org/boletin/b11/ consulta em 02/05/2005.
} 
musas hollywoodianas ou cantoras pops, submetendo-se às normas estabelecidas.

Se "ser travesti" é algo continuado e sem fim, este processo pode ser dividido em algumas etapas. A primeira delas é quando ainda se é "gayzinho" (classificação êmica), ou seja, já assumiu a orientação sexual para familiares e para "a sociedade" (como elas dizem, para um conjunto mais abrangente de pessoas), mas ainda não se vestem com roupas femininas ou ingerem hormônios. A fase seguinte é "montar-se", que significa, no vocabulário próprio do universo homossexual masculino, vestir-se com roupas femininas, maquiar-se de forma a esconder a marca da barba, ressaltar maçãs do rosto, evidenciar cílios, as pálpebras dos olhos e a boca. Nessa etapa, vestir-se com roupas femininas ainda é algo ocasional, furtivo, restrito a momentos de lazer. 0 terceiro momento é o da "transformação", uma fase mais nuançada, pois tanto pode envolver apenas depilação dos pêlos do corpo e vestirse cada vez mais freqüentemente como mulher, como pode indicar o momento inicial de ingestão de hormônios, quando estes ainda não mostraram efeitos perceptíveis; finalmente, a quarta etapa, quando já se é travesti, além do consumo de hormônios, vestem-se todo o tempo com roupas femininas (sobretudo roupas íntimas, pode estar de shorts, sem camisa, mas de calcinha) e planeja injetar silicone nos quadris e nádegas.

A transformação seria esse processo de feminilização que se inicia com extração de pêlos da barba, pernas e braços, afina a sobrancelha, deixa o cabelo crescer e passa a usar maquiagem e roupas consideradas femininas nas atividades fora do mundo da casa. A seguir, começam a ingestão de hormônios femininos (pílulas e injeções anticoncepcionais e/ou de reposição hormonal), passando por aplicações de silicone líquido nos quadris e, posteriormente, nos seios, até chegar (e nem todas podem fazê-lo por absoluta falta de dinheiro) a intervenções cirúrgicas mais radicais - plástica do nariz, eliminação do pomo-de-adão, redução da testa, preenchimento das maçãs do rosto e colocação de prótese de silicone. 
Na noite nem todos os gatos são pardos

São poucas as que conseguem essa transformação tão apurada. Normalmente, as que a alcançam são as tops e/ou "européias". ${ }^{9}$ As primeiras são travestis que fazem filmes de sexo explícito e ensaios fotográficos de igual teor. São tidas pelas demais como "belíssimas". Muitas delas têm acesso freqüente à Internet, onde mantêm blogs e fotoblogs. ${ }^{10} \mathrm{O}$ uso contumaz das plataformas disponibilizadas pela Internet as faz mais conhecidas e prestigiadas, o que permite que cobrem até $R \$ 150,00$ por uma hora/uma hora e meia de programa completo (sexo com penetração).

Gladys Adriane, travesti top, acredita que uma verdadeira top deve falar pelo menos dois idiomas. Ela fala inglês e espanhol, além do português, e espera voltar de sua temporada na Itália versada no italiano.

As tops têm que falar outros idiomas, mas não devem falar o bajubá ou pajubá (se usa ambos os termos), gíria própria das travestis que tem sua origem no ioruba-nagô. A top Juliana Nogueira comenta que na casa onde morava havia uma caixinha para depositar a multa de $\mathrm{R} \$ 1,00$ por se falar bajubá.

Outro requisito citado por Gladys e por Victória Ribeiro, também reconhecida como top, aponta para os cuidados estéticos, o que inclui o uso de produtos de marcas caras: "das pontas das unhas dos pés ate o último fio de cabelo deve ser intacto e o mais perfeito possíveis... pele então...", declara Gladys

\footnotetext{
9 Algumas classificações não são excludentes, podendo uma top ser "européia", ou um "travecão" já ter sido top, assim como uma t-gata (como são chamadas as travestis que freqüentam o Dia T) pode ser "ninfetinha" ou top. Além disso, ser to $p$ ou "européia" não restringe a forma de trabalho. Como me declarou certa vez uma top, se as coisas não vão bem via Internet ou celular ela vai para a rua, vai "fazer pista".

${ }^{10}$ Os blogs e fotoblogs são plataformas de sociabilidade virtual que agem como murais de notícias e se diferenciam das webpages, pois permitem que os visitantes da página digitem comentários sobre temas ali discutidos, sobretudo os fotoblogs, sobre as fotos e/ou pessoas e/ou eventos que as mesmas retratam DORNELLES, J . Antropologia e Internet... Op. cit.
} 
em conversa via MSN. ${ }^{11}$ Victória, que usa produtos para cabelos da marca kerastase, comprava xampus que custavam de $\mathrm{R} \$ 40$ a $\mathrm{R} \$ 60$. Gladys diz que

Praticamente $70 \%$ dos meus ganhos é em minha imagem... agora não, eu tracei outras metas e quando você vai ficando com a imagem que desejou passa a gastar um pouco menos...

Ser uma top ou "européia" pode significar a mesma coisa. No entanto, nem toda "européia" é top, assim como nem toda top é "européia". Para ser européia tem que ter vivido uma temporada atuando como prostituta fora do Brasil. Esse fluxo migratório se acentuou nos anos de 1980 e, até o momento, mantém-se como sonho de ascensão social dentro do grupo pesquisado, dado 0 acesso a bens materiais e simbólicos que 0 dinheiro auferido nessas viagens pode proporcionar.

Quando Paris era o sonho de ascensão das travestis, imperava o estilo "travecão" - ancas fartas, seios grandes, boca carnuda, coxas volumosas. O exagero é a marca desse "corpo Paris", e é justamente 0 excesso que remte à imagem masculina. Como aponta Fabyanna Toledo, nesse momento em sua primeira temporada na Europa, "um travecão nunca passará por mulher".

o "travecão" está ligado ao exagero, ao masculino e, portanto, ao insucesso ou ao ultrapassado. O estilo valorizado atualmente é a "ninfetinha", mais natural - curvas mais enxutas, seios menos exagerados, roupas mais ao gosto das adolescentes que aparecem em programas televisivos como Malhação ${ }^{12}$-,

\footnotetext{
${ }^{11}$ Programa de instant messanging, isto é, conversa em tempo real, por meio do qual o usuário, depois de baixar o programa e abrir um e-mail no provedor Hotmail, pode anexar outros usuário que também tenham o serviço e conversar com eles. As caixas de diálogo permitem visualizar fotos, enviar arquivos, convidar integrantes para conversar numa mesma janela.

${ }^{12}$ Soap opera veiculada pela Rede G lobo de televisão no horário da tarde.
} 
Na noite nem todos os gatos são pardos

"fazendo a linha Patricinha". ${ }^{13}$ Como as adolescentes e jovens heterossexuais, as travestis também se deixam sedużr pelos apelos da moda, por padrões estéticos rigidamente estabelecidos pela mídia, assim, muitas delas reproduzem esses valores estéticos em busca de legitimidade

O conjunto de padrões estéticos das travestis está ligado a valores morais próprios do grupo. Por exemplo, o "gayzinho" só é tolerado se apresentar um visual andrógeno e indefinido na fase inicial da transformação. Depois disso a pessoa passa a ser vista como desleixada ou mesmo covarde, por não ter coragem de ir a fundo na transformação.

Os "travecões" denunciam o insucesso na transformação e a idade, enquanto as "nifetinhas" e/ou "Patricinhas" são jovens, valor cultivado no grupo, pois as coloca em melhor posição no mercado sexual, podem ter acesso a toda uma tecnologia estética que não estava disponível até muito recentemente, o que as torna "mais bonitas" e melhor sucedidas em seu processo de transformação. As mais velhas, "travecões" ou não, consideram que as "ninfetinhas" são desrespeitosas e arrogantes - "abusadas". 0 que aborrece as veteranas é que as jovens não admitem sua inexperiência e esnobam aquelas que "abriram as portas para elas".

Paulette, que se iniciou como travesti e prostituta na década de 1970 relembra:

Ah, quando eu comecei era muito difícil. Era muito difícil porque era naquela época da ditadura, a gente não era visto como travesti, que eles chamavam a gente era de pederasta. A panhava na rua, ia preso no Deic. Eu cansei de ficar no Deic oito dias lá dentro, no porão, onde ninguém sabia que hora era. Se era dia, se era noite.(...) Muitas se cortavam. Muitas se cortavam, se retalhavam pra poder sair. Eu conheci até uma que era chamada, não sei se ela

\footnotetext{
${ }^{13}$ Fazer a linha significa "agir como se fosse".
} 
ainda é viva, Patrícia Decorada, de tanto que ela se cortava.

A história de que a travesti anda com giletes escondidas na boca para se defender dos perigos da noite é uma lenda que perpassa o grupo e a polícia. Em épocas mais repressivas, ao serem presas, as travestis se cortavam, procurando ser soltas ou levadas para um pronto-socorro. Com o surgimento da aids esta prática tornou-se mais eficiente, dado o pânico que causava 0 contato com o sangue de um grupo associado à doença.

A noite é um doce ${ }^{14}$

O rol de ameaças para as travestis que estão "na pista", é longo - repressão policial, assaltos, brigas, ofensas proferidas pelos transeuntes... Elaine conta sua experiência:

A avenida é muito boa pra quem é informado. Pra quem sabe o que tá fazendo ali. Mas pra quem não sabe, pensa que é um mar-de-rosas tudo aquilo... porque a avenida só é boa quando você come um quilo de sal nela. Porque antes você se deslumbra. Eu me deslumbrava... [me sentia] maravilhosa, porque eu batia porta. ${ }^{15}$ Mas quando levei a primeira ovada, extintorada, a primeira surra, porque você leva. Tem sempre uma que se incomoda com você, e você leva, ela te manda alguém te dar uma surra, você começa a ver como é que é. Porque você sabe, quando você incomoda... se você incomoda muito você sabe que vai tá sempre tirando uma inimizade, incomoda. Por mais que eu te beijo, te abraço, se você tá incomodando ela, você é uma rival pra ela. Então se ela não puder fazer nada pra você, ela vai mandar alguém fazer.

\footnotetext{
${ }^{14}$ Expressão comum entre as travestis entrevistadas, que associa "avenida" à prostituição de rua. A palavra "doce" a algo que é ruim. Mandar um doce para alguém é armar uma cilada, provocar uma situação desagradável e/ou violenta.

${ }^{15}$ Fazer programas, uma alusão a entrar no carro do cliente.
} 
Na noite nem todos os gatos são pardos

[Pesquisadora - Manda um docinho?!]

Manda um docinho?! Manda um bolo, minha filha, um bolo confeitado! Que doce o quê! [risos]. Então, até você ir ganhando a manha....

A té pegar a "manha", medo e insegurança são situações de ameaça enfrentadas pelas travestis que se prostituem. Mesmo as veteranas não estão isentas de sofrerem violência. Uma noite, sentada na calçada em uma rua de Santo Amaro, bairro paulistano, conversava com um grupo de travestis mais velhas, quando uma "nifetinha" aproximou-se um tanto desolada, pois acabara de ser roubada por um suposto cliente, que havia levado sua bolsa. A indiferença foi geral. Mais tarde Checheu, da turma das veteranas, comentou: "A bicha queria dar close [esnobar] pra gente, dizer que bate porta. Eu, hein?! Conheço esses tipos de longe".

Depois desse episódio percebi que ficou um certo peso no ar, mas nenhuma delas estava interessada em conferir àquele fato muita relevância. Certamente, eu era a mais impressionada. Perguntei se aquele sujeito teria coragem de aparecer ali de novo, o que elas fariam se ele viesse: "Aparece!! Ih, filha, esses caras... bandidinho", assegura Checheu.

Checheu lembra de uma noite que um tipo como aquele saiu com uma das travestis:"Roubou ela e depois ainda veio dar carona pra mim". Disse, ainda, que se o cara aparecer com dinheiro, sempre terá uma que irá fazer o programa com ele.

$A$ indiferença parece estar relacionada à rivalidade entre as veteranas - escoladas, já não tão atraentes - e a travesti "ninfetinha" - inocente, mas apetitosa -, mas também uma forma de criar uma carapaça, ante a fatos corriqueiros, para aturar a vida na noite.

Nessa noite de muita "função", homens passavam em carros cheios, motoqueiros, rapazes de bicicleta, todos com 0 
propósito de rirem, humilharem, se divertiram às custas das travestis. "Fazer função" pode envolver jogar ovos, garrafas, cuspir e outras ações violentas. Quando a violência é mais explícita, envolvendo danos físicos, elas chamam de "curra". Essas travestis contam que não faz muito tempo sofreram uma curra. Alguns motoqueiros ligados à cafetina do lugar, em um suposto acerto de contas pelo que tinha acontecido com a tia deles, obrigaram algumas travestis a fazer sexo oral sem pagar, e sem preservativos, além de bater nelas. Essas histórias são recorrentes nas narrativas, mas também presenciei muitas "funções".

Esses episódios as deixam sempre em estado de alerta, prontas a reagirem, razão pela qual muitas possuem armas brancas que, por vezes, acabam sendo utilizadas contra as colegas de rua. Algumas justificam que esse tipo de cotidiano as faz beber muito e se "colocar" - usar drogas.

Recentemente, o crack ganhou espaço entre as travestis, levando muitas delas, no desespero, a fazer programas por $\mathrm{R} \$$ 5,00 , preço de uma "pedra". Além do álcool, a droga mais consumida nas noites, a cocaína também é bastante usada. Um cliente relatou que sua aproximação com as travestis se deu exatamente por causa de seu vício em pó: "elas sempre têm o melhor, ou sabem quem tem".

No geral, as travestis namoram garotos de programa, traficantes, puxadores de carro, homens da noite, o que facilita 0 acesso às drogas. Muitas dizem que "de cara limpa" é muito difícil suportar a rotina da prostituição, outras alegam o abandono que sentem da família, a discriminação diária e o sentimento de solidão. J ennifer, minha informante privilegiada em São Carlos, vê o uso de drogas como parte da sedução inicial que a noite exerce sobre quem passa a viver a rotina de se prostituir. 
Na noite nem todos os gatos são pardos

Mãe, madrinhas e madrastas... é babado ${ }^{16}$

É comum o processo de transformação das travestis se iniciar com a ruptura do mundo da casa, seguido pelo necessário apego ao universo da rua, onde encontram formas de sobrevivência e aprendem, ou potencializam, seu processo de transformação. Em busca de si mesmas, de sua "autenticidade", vão inscrevendo seus sonhos em seus corpos. Para isso, precisam contar com a ajuda do grupo, é difícil se tornar travesti sem estar inserido em uma rede específica e, neste processo, o "amadrinhamento" é essencial.

Muitas travestis se orgulham de serem "mães" ou "madrinhas", termos que às vezes adquirem o mesmo sentido. "Amadrinhar" geralmente se refere a proteger e ensinar viver como travesti, cabendo à categoria de "mãe" a iniciação propriamente dita. Gladys Adriane, travesti que vive atualmente na Itália, aponta que, normalmente, "as mães" são as cafetinas. Com uma fina ironia, Gladys fala da relação de afetividade entre travesti e cafetinas: "Só se a filha não ficar devendo. Aí querida, a mãe vira madrasta rapidinho. É babado!".

Hillary Week ${ }^{17}, 17$ anos, conta sua experiência de aprender a ser travesti com Cláudia, a quem via como uma mãe:

[Pesquisadora - Como é se mãe de Hilary?]

Cláudia - É ensinar para elas e para as outras que tem que guardar seu dinheirinho. Falar das drogas. Ensinar as coisas. Não quero que ela passe pelo que eu passei.

\footnotetext{
${ }^{16}$ Babado pode significar algo muito bom; uma novidade que se conta (geralmente boa); um acontecimento interessante, divertido e/ou com episódios surpreendentes; algo bom. Porém, dependendo do contexto, pode significar algo que vai ter conseqüências ruins.

${ }^{17}$ Hillary passava por um momento assim em maio de 2004, quando a conheci. A última informação que tive foi sobre seu internamento em uma clínica para se "limpar" do crack. Na época, ela não morava mais com os pais, acabara de deixar seu nome de rapaz, passara a tomar hormônio e a se vestir diuturnamente de mulher.
} 
[Quero saber de Hillary o que ela tem aprendido com Cláudia]

Hilary - É assim: dou um passo errado, ela me fala que não é assim que se pisa. Que desse jeito vou me dar mal. Fazeu voltar e dar de novo o passo, agora certo.

Cláudia quando era "cafetina" tinha o dever de proteger as travestis que se uniram a ela ou viviam em sua casa. Ela era mais vivida e, supostamente, tinha muito a ensinar.

Alessandra, vivendo na época em São Carlos, explica que o "respeito" à cafetina está em não invadir o ponto dela, não roubar, não mandar "doce". Ela também diferencia o "cafetão" da "cafetina".

A cafetina é igual a você, sabe o que você passa. Ela te cobra não pra se manter, pra te defender. Ela te cobra pela moradia, não é aquela coisa... Ela cobra o preço que você pode pagar. Cafetão já é diferente.

Carla, que vive em São Carlos na casa da cafetina Verônica, aponta que Verônica é muito boa e que em sua casa não há regras rígidas, muito diferente da casa que morou em São Paulo, onde a comida era racionada, os horários extremamente rígidos e a diária pelo aluguel, refeições e proteção era cobrada com rigor. Carla lembra que a temida cafetina promovia algumas escolhidas, levando-as para "fazer o corpo" (injetar silicone) ou mesmo para colocar próteses, "deixando-as belíssimas": "Ai daquela que traísse ela, roubasse, se colocasse, ficasse devendo... era babado. Ela não tinha dó. A bicha tava marcada. Não tinha essa moleza que é na casa aqui".

Verônica reconhece que em sua casa não há muitas regras, mas nem por isso deixa de cobrar "multa", expediente comum entre travestis, seja a cafetina com suas filhas, as mais velhas com as que vão chegando na avenida, exigindo o "pedágio", pagamento para que as novatas possam trabalhar no local, seja 
Na noite nem todos os gatos são pardos

com clientes que descumprem o que foi tratado na "entrevista". A "multa" é uma espécie de castigo - pago em dinheiro ou mesmo objetos (perfumes, roupas, acessórios são os mais comuns) aplicado por infração de regras, má conduta, invasão de ponto e, no caso de clientes, por descumprirem o que foi acordado em relação ao programa. Obviamente esse último expediente só pode ser praticado pelas tops, pois atendem em condições mais confortáveis e seguras, além de trabalharem com homens mais endinheirados e temerosos de escândalos.

Um episódio envolvendo uma travesti top e um cliente ilustra bem essa situação. ${ }^{18} 0$ cliente entrou em contato com a travesti via celular para agendar um programa, deixando claro que dinheiro não era problema, mas que gostaria de ter tempo, que ela não ficasse cronometrando o programa. 0 encontro virou tema do fórum de discussão de homens que saem com travesti, porque o cliente foi multado. Segundo o cliente, a multa foi aplicada porque ele, que gosta de ser passivo, havia "passado cheque" (sujado o pênis da travesti com fezes). Ainda de acordo com o relato, ao perceber o ocorrido a travesti retirou a camisinha com fúria, sujando o lençol. Pelas despesas com lavanderia, a travesti teria cobrado $\mathrm{R} \$ 20,00$.

0 cliente relata que sua indignação, não pelo valor da multa, mas pelo fato desta ter sido aplicada. Além disso, ele enfatiza 0 fato de ter sido humilhado pela travesti, que gritou no corredor do prédio onde mora e atende que ele se lavasse melhor da próxima vez, que não fosse uma "maricona" sem asseio.

\footnotetext{
${ }^{18} \mathrm{O}$ caso que passo a narrar foi relatado pelo próprio cliente em um fórum de debates voltado exclusivamente para homens que saem com travestis e para elas mesmas.
} 
Bofes, mariconas e vícios - a clientela a partir do olhar do grupo

Antes de falar dos clientes, considero importante apresentar a categoria marido/namorado, pois esta oferece um contraponto com os homens da rua e ajudam a perceber a relação com a clientela.

"Travesti não tem namorado, tem marido", aponta Danil, um jovem de 22 anos que, desde os 15, se relaciona com travestis. Ele está apaixonado por Paola, uma travesti dois anos mais velha, que abdicou do sonho de ir para a Europa para ficar ao lado dele. Giselle, experiente travesti paulistana, esclarece que "marido" é mais de uma gíria do meio, do que a caracterização de laços conjugais - dividir o mesmo teto e repartir obrigações. ${ }^{19}$

A categoria "marido" sugere que nas as relações amorosas envolvendo travestis o tempo de consolidação dos laços, e dos compromissos, é distinto daquele que envolve relacionamentos de contornos heterossexuais e de classe média. ${ }^{20} \mathrm{Nada}$ de encontros cercados de amigos, flertes em barzinhos, passeios de mãos dadas em shoppings, saídas para jantares ou reuniões em casas de parentes. Além disso, travestis costumam ter uma trajetória de vida que as distancia dos padrões de comportamento considerados adequados para certas faixas etárias, mesmo entre camadas populares - saem cedo de casa, em torno dos 14 anos, e geralmente iniciam uma vida noturna sustentando-se através da prostituição.

\footnotetext{
${ }^{19}$ Heilborn considera que "a conjugalidade não emerge de um fato jurídico. É isto sim, o que expressa uma relação social que condensa um 'estilo de vida', fundado em uma dependência mútua e em uma dada modalidade de arranjo cotidiano, mais do que propriamente doméstico, considerando-se que a co abitação não é regra necessária". HeILBoRN, M. L. Maria Luiza. Dois é Par Gênero e Identidade sexual em contexto igualitário. Rio de Janeiro, Garamond, 2004, pp.11-12.

${ }^{20}$ Para uma discussão aprofundada de padrões de conjugalidade nas camadas médias urbanas ver ID., IB., capítulo 3.
} 
Na noite nem todos os gatos são pardos

Por serem muito jovens, precisam aprender a "dar 0 truque" ${ }^{21}$ : parecerem mais velhas, driblar as situações de violência que podem vir tanto dos clientes como da polícia, e não raro de pessoas do seu grupo de convivência. A prender os códigos da rua e da noite significa sobrevivência, e isso não é coisa de criança nem de adolescentes. Bruna, 24 anos, desde o 14 na prostituição travesti, diz:

Quando eu cheguei em São Paulo, depois de fugir de casa de carona, fazer sete programas no caminho, procurar a casa da cafetina... Quando eu cheguei em frente ao prédio dela, eu olhei pro céu e pensei: "pronto, agora eu sou dona do meu nariz! Agora eu sou adulta".

Não há espaço para relações pautadas pelos "roteiros" comuns à classe média heterossexual. Ainda assim, as travestis, informadas pelos códigos conjugais heteronormativos, almejam uma vida conjugal nos moldes instituídos: casa, marido "homem de verdade", tranqüilidade financeira, trabalho "normal", o que significa fora de noite e da prostituição e, se possível, filhos.

Carol, não admite fazer papel de "homem" com seus namorados. Queixa-se de um deles que insinuava querer ser penetrado, mas que ela nunca satisfez esse desejo, por isso ele procurou realizar sua fantasia com outros travestis. Ofendida, Carol se viu duplamente traída: não só pelo por ele ter feito sexo com outras, mas por ele, seu homem, ter feito "papel de mulher" com outras pessoas.

Ao me mostrar a revista Travestis, ela aponta para uma foto em que um "homem" de bigode e pêlos faz felação em um travesti com seios como de qualquer mulher, cintura bem definida, coxas roliças, cabelos longos e loiros: "Eu jamais admitiria um namorado meu fazer isso comigo...". Mas, se necessário, Carol também cede,

\footnotetext{
${ }^{21}$ Enganar, fazer-se passar por, se virar com que se tem, otimizando atributos físico s e habilidades em geral.
} 
profissionalmente, ao papel de ativo. $\mathrm{Na}$ vida íntima essa possibilidade a deixa irritada, com nojo.

No comércio sexual em geral, existem claras demarcações das práticas sexuais - o que se pode fazer na rua, com clientes, e o que não se deve fazer, contrastando com aquelas que são reservadas aos maridos, portanto, ao espaço doméstico, da casa, dos afetos.

Nas relações conjugais envolvendo travestis, "homens de verdade" devem se relacionar com pessoas que nunca serão "mulheres de verdade". As travestis entrevistadas não almejam serem mulheres, mas parecerem mulheres. Isso significa mais do que estampar no corpo atributos físicos próprios de mulher biológica, mas investir em uma educação corporal e moral que conforma um ethos próprio do grupo.

O potencial "marido" dessas travestis é o bofe, um "homem de verdade", aquele que reproduz no seu comportamento valores próprios da masculinidade hegemônica. ${ }^{22}$ Se os "homens de verdade", os bofes, acabam incitando o desejo das travestis a ponto de fazê-las "perder a cabeça" - fazer sexo sem preservativos, gastar dinheiro que não têm para satisfazê-los e mimá-los -, as "mariconas" ficam loucas por elas e acabam deixando de lado o chamado "sexo seguro". Fabyana Tolledo diz

\footnotetext{
${ }^{22}$ Vale de Almeida define a masculinidade hegemônica como "um modelo cultural ideal que, não sendo atingível por praticamente nenhum homem, exerce sobre todos os homens um efeito controlador, através da incorporação, da ritualização das práticas da sociabilidade quotidianas de uma discursividade que exclui todo um campo emotivo considerado feminino; e que a masculinidade não é simétrica de feminilidade, na medida em que as duas se relacionam de forma assimétrica, por vezes hierárquica e desigual. A masculinidade é um processo construído, frágil, vigiado, como forma de ascendência social que pretende ser. (...) Segue-se que as masculinidades são construídas não só pelas relações de poder mas também pela interrelação com a divisão do trabalho e com os padrõ es de ligação emocional. Por isso, empiricamente, se verifica que a forma culturalmente exaltada de masculinidade só corresponde às características de um pequeno número de homens". VALE DE ALMEIDA, Senhores de Si - um interpretação Antropológica da Masculinidade. Lisboa, Fim de Século, 2000, pp.17 e 150.
} 
Na noite nem todos os gatos são pardos

que há clientes que "já vêm chupando, sem pedir nada. É babado!". Esses homens, em outros contextos, não assumem suas práticas sexuais, mas "depois vem pedindo pra gente gozar na boca deles. $\mathrm{E}$ depois de tudo, aí sim vão perguntar se a gente tem alguma coisa".

Nesse sistema de gênero, que parece rigidamente binário, uma das categorias problemáticas de classificação se aplicaria à "maricona", por não se alocar coerentemente em nenhum dos dois pólos. O que é ser uma "maricona"? 0 termo já foi usado para classificar homens efeminados e mais velhos, mas para os grupos de travestis que participam dessa pesquisa é uma espécie de xingamento, uma ofensa dirigida a certos tipos de homens aqueles que até passariam por "homens de verdade" na vida pública, mas que na privacidade das práticas sexuais escapam para o desprestigioso pólo feminino.

Via de regra, ser "maricona" também está relacionado com pertencimento de classe e grupo etário, assim como as demais classificações atribuídas aos clientes - "penoso", "varejão", "truque" e "fino".

0 "penoso" é o cliente que nunca tem dinheiro, estampa essa carência em suas roupas e meio de transporte - a pé, bicicleta, moto, carros velhos -, no geral, são trabalhadores braçais, que pertencem à mesma classe social das travestis, comungando valores e representações sobre sexualidade e papéis de gênero, o que, teoricamente, tornaria a negociação - a chamada "entrevista" - mais fácil, não fosse barreira financeira, que o coloca em condição desprestigiada. No entanto, esses clientes têm aparência mais máscula, o que agrada grande parte das travestis do grupo pesquisado. É raro pedirem para "fazer passivo", pois operam em um sistema de sexo/gênero que entende o verdadeiro homem como aquele que não faz sexo anal, mesmo quando em relação com um outro homem. 0 "penoso" pode ser um jovem ou um senhor, pois sua classificação se dá, sobretudo, a partir de seus atributos materiais. 
O "varejão" é normalmente um rapaz com performance mais ousada, arrisca-se mais, tenta passar as mãos nas travestis, pede para ver partes de seus corpos, como os seios e o pênis, podendo ser rechaçado e mesmo agredido verbal ou fisicamente. Por ser mais jovem, muitas vezes, não tem renda própria, mesmo que tenha não é suficiente para esse tipo de gasto. Como o "penoso", ele também pechincha. Além disso, diz Evelyn - travesti que trabalha em São Carlos -, o "varejão" é geralmente bonito e acha essa qualidade suficientemente sedutora para que a travesti queira fazer sexo com ele sem cobrar. Penso que essa "beleza" está relacionada com a sua juventude e com a aparência que reproduz os atributos físicos considerados desejáveis para um macho.

O "truque" é um tipo mais escorregadio, exatamente porque é capaz de enganá-las, ao aparentar um poder aquisitivo elevado, prometem um pagamento que não poderão cumprir. Esse é o tipo mais "perigoso", pois não se sabe o que esperar dele.

Muitas "mariconas" podem se enquadrar no perfil do "fino" - um cliente cortês, bem apessoado - o que é indicado pelos seus trajes e meio de transporte, geralmente automóveis de modelos mais novos e caros. Eles são quase sempre mais velhos que as travestis, seus bens materiais e seu comportamento indicam que pertencem à classe média. Sair com um cliente com esse perfil dá prestigio à travesti, ainda que durante o programa ela venha a se surpreender com seus desejos pouco "másculos" para os padrões do grupo.

$\mathrm{Na}$ visão das travestis envolvidas nessa pesquisa, bem como o discurso hegemônico sobre sexualidade, esses homens não seriam menos homens apenas por procurarem sexo com travestis, mas, sobretudo, por buscarem um determinado tipo de sexo. "Com a gente eles não querem nada do convencional", aponta Letícia, travesti paulista. O "não convencional" desestabiliza o "homem de verdade", porque as práticas sexuais com as travestis envolvem desde a felação (eles nelas) até o sexo anal (elas como 
Na noite nem todos os gatos são pardos

"ativas" $)^{23}$, passando por práticas sado-masoquistas, fetichismos, entre outras.

Butler, numa releitura de Douglas, argumenta que "o sexo anal e oral entre homens estabelece claramente certos tipos de permeabilidade corporal não sancionado pela ordem hegemônica". ${ }^{24}$ Essa permeabilidade desestrutura a pretensa ordem social que demarca com suas regras e tabus o que deve ser esse corpo (físico e social).

Assim como a "maricona", o "vício" também é uma categoria problemática. Porém, como o bofe, pode ser visto como "homem de verdade" Ao contrário do marido, seu lugar não é a casa, o espaço afetivo, tampouco é como o cliente, alguém que paga pelo sexo, com quem se relacionam "profissionalmente", sem beijo na boca, com tempo pré-determinado. 0 "vício" flutua entre a casa e a rua, a noite e o dia, apesar disso, é um elemento mais noturno e do espaço das transações comerciais, ainda que não seja interditada a ele uma série de práticas - o beijo na boca, sexo sem camisinha. Outra questão problemática envolvendo o vício é o fato de não serem cobrados os momentos passados ao seu lado, muitas vezes, o "vício" pode vir a ser um namorado/ marido.

O "vício" é uma categoria depreciativa quando se aplica às próprias travestis. Para o grupo estudado, uma travesti "viciosa" é alguém que não sabe separar trabalho de afeto, planos opostos e imiscíveis. A "viciosa" compromete os negócios de todas que estão próximas dela, porque tende a sair de graça com homens

\footnotetext{
${ }^{23}$ Os programas custam em media $\mathrm{R} \$ 30$, quando envolvem penetração. Nas áreas mais prestigiadas cobra-se $R \$ 50,00$, mas são valores negociáveis. Sexo oral custa em média $R \$ 15,00$, o mesmo preço da masturbação, que com um pouco de negociação pode sair por $R \$ 10,00$. Algumas dizem que cobram mais para serem ativas ou para beijarem na boca. A despesa como drive-in ou motel fica por conta do cliente. As tops cobram a partir de $\mathrm{R} \$ 150$, muitas oferecem atendimento privê, isto é, em local próprio.

${ }^{24}$ ButLer, J. Problemas de Gênero: feminismo e subversão da identidade. Rio de Janeiro, Civilização Brasileira, 2003, p.190. Mesmo pensadas em um contexto distinto, as afirmações da autora ajudam nas reflexões aqui propostas.
} 
desconhecidos; também paira sobre ela a suspeita de que "não se cuida", pois se deixa levar pelos afetos de ocasião.

Existem também os homens viciosos, aqueles que estão sempre tentando sair com elas sem pagar e sem querer envolvimento afetivo. Esses são "podres", merecem desprezo. Entre as ofensas mais recorrentes aos homens, principalmente aos clientes, é a locução "maricona viciosa", associando assim dois comportamentos desprestigiados nesse grupo.

A pesar dessa gama de classificações, as travestis informam (e minhas observações confirmam) que seus clientes, no geral, são casados, se concentrarem na faixa dos 30 a 45 anos e buscam sexo pago também com mulheres.

Sob a ótica dos clientes entrevistados, tema vasto e que não será tratado aqui, as travestis são objetos de desejo temeroso, não só pela prática que coloca em cheque sua masculinidade como também pela idéia generalizada, e fundamentada, de que muitas travestis têm aids e que roubam. Por isso, os clientes que têm acesso a Internet trocam dicas sobre segurança, além de outras informações seja sobre 0 a paradeiro de uma determinada travesti, sobre preço e esquemas de programas, entre outros. ${ }^{25}$

Essa realidade tem se mostrado importante entre a clientela: o uso da rede mundial de computadores para acessá-las, obter e trocar informações, extravasar seus desejos e medos, baixando vídeos e ensaios pornôs ou conversando com elas em chats, sem contar a sociabilidade que alguns grupos criaram nesses ambientes on-line ${ }^{26}$.

Se os homens se conectam à rede, entre elas esse também é um fenômeno crescente, sobretudo, entre aquelas que conseguem

\footnotetext{
${ }^{25}$ Ao contrário do que pode se pensar, questões relativas à aids e outras doenças sexualmente transmissíveis são secundárias nesses fóruns de discussão.

${ }^{26}$ Para uma discussão mais aprofundada sobre a clientela ver Pelúcio, L. Sexualidade, gênero e masculinidade no mundo dos t-lovers - a construção da identidade de um grupo de homens que se relacionam com travestis. http//www. sbsocio logia. com.br/congresso/gt00. asp?idcongrsso $=4$.
} 
Na noite nem todos os gatos são pardos

realizar o grande sonho das travestis brasileiras que vivem da prostituição: ir para a Europa.

"Belíssimas"

Niky é "belíssima". Acima de tudo, o que a faz belíssima é ser "toda quebrada na plástica", tornou-se arredondada, suavizou tudo o que era anguloso, duro e reto: características atribuídas ao corpo masculino. Fez nariz e testa, refez seios e abdômen, cultiva cabelos longos e naturais, aos quais dedica muitos cuidados, tem a pele bronzeada, as marcas do biquíni delineiam contornos. No rosto, nem um vestígio de pêlos pode ser detectado. Boa parte do dinheiro investido nessa transformação foi conseguido através de suas temporadas na Itália, onde trabalha como prostituta. Como Niky, dezenas de travestis brasileiras estão, neste momento, trabalhando na Itália, país que se transformou no sonho de ascensão de grande parte do grupo. Em 1980, Paris era o destino. $\mathrm{H}$ avia possibilidades de bons ganhos na capital francesa, ainda que as condições de trabalho fossem sacrificadas, pois tinham que se esconder em parques e bosques, enfrentando o frio do invemo europeu, correndo da polícia de imigração entre outros contratempos relatados pelas mais velhas. No entanto, na Europa existe algo que todas as travestis repetem: o respeito à sua condição, como narra Marguinha Minelli:

Paris, vocês sabem, é babado e confusão! Comecei a me montar e dá-lhe hormônio na boneca...quando a gente vem pra Europa e se põe de mulher, os homens gostam muito, uma coisa impensável para o Brasil...aí [refere-se ao Brasil] é "curra" e aqui é glamour... ${ }^{27}$

Passados os anos dourados de Paris, na década de 1990 a Itália se consagrou como o destino daquelas que desejavam

\footnotetext{
${ }^{27}$ Entrevista disponível no site Casa da Maitê. http://hosting.pop.com.br/glx/ casadamaite/sexualidade/travestis/entrevistas/entre1 9. html
} 
dinheiro e fama. Porém, esse também foi um momento de grande histeria em torno da aids, atribuída na Europa, assim como no Brasil, aos gays, às travestis, às prostitutas, aos drogados, enfim, aos "corpos desviantes". Esse verdadeiro "pânico moral" 28 desencadeou fortes ondas repressivas, que provocou um refluxo migratório, hoje já superado.

Apesar de recente notícia com tom de denúncia veiculada por diversos jornais, a prostituição travesti na, e para a, Europa não é alimentada por tráfico de seres humanos ${ }^{29}$, mas pela opressão material e simbólica que circunscreve as travestis em guetos, dificultando o acesso à escolaridade, ao mercado de trabalho e comprometendo seus projetos de transformação e inserção social fora da prostituição.

Atualmente, Milão ainda é a Meca travesti, onde são tratadas por signorina e não são alvos de olhares escrutinadores to do o tempo. Mas a península Ibérica tem começado a ganhar destaque no mapa da ascensão das travestis. Fabyana Tolledo, neste momento na Espanha, conta em entrevista via MSN como tem trabalhado por lá:

Aqui funciona assim, só se fica 21 dias em cada piso [casas de prostituição gerenciadas geralmente por travestis] e em conseqüência também se muda de cidade, porque todas são pequenas. (...)

\footnotetext{
28 “Na década de 1960, Stanley Cohen desenvolveu uma reflexão sobre como a sociedade reage a determinadas situações e tipos sociais que presume representarem alguma forma de perigo. 0 então estudante de doutorado da Universidade de Londres explico u o processo de sensibilização social em que um tipo de comportamento e uma categoria de desviantes são id entificados de forma que pequenos desvios da norma são julgados e recebem uma forte reação coletiva. Assim, Cohen criou o conceito de pânico moral para caracterizar a forma como a mídia, a opinião pública e os agentes de controle social reagem a determinados rompimentos de padrões normativos. MISKOLCI, R. Pânicos Morais e Controle Social - Reflexões sobre o Casamento Gay. Mimeo, 2004.

29 http://www.smm.org.br/noticias/rede_trafico.htm, http://www.mp.pe.gov.br/ imprensa/imprensa_clipping/noticias/2005_ago sto/11_acusado.htm
} 
Na noite nem todos os gatos são pardos

[E o preço do programa aí?]

$\mathrm{Na}$ maioria 30,60 euros, por 45 minutos, 100, 120 é $1 \mathrm{~h}$.

Aqui só muda o de 45 minutos que custa 80 .

0 atendimento nesses casos é sempre nos referidos pisos ou até mesmo em apartamentos próprios (alugados ou comprados), o que é mais raro. As que trabalham dessa forma normalmente estão em outro patamar, já têm fama e tempo suficiente na Europa para assegurar sua autonomia, não pagando nada a agenciadores e/ou cafetinas/cafetões. As novatas, que embarcam com "financiamento" de agenciadores (muitas vezes uma travesti "européia" ou mais velha), tem de dar metade do preço do programa para a administradora do local, além de guardar parte desse dinheiro para quitar as despesas do financiamento, entre seis e 13 mil euros. Segundo um informante, os custos com passagens e assessoria inicial não passam de três mil euros, 0 restante é o ganho do/da "financiador/ financiadora". Algumas conseguem pagar seis mil euros em três meses, mas há as que "penam". Quando pergunto ao informante se essas sofrem represália ele me diz que há muito mito em torno da violência, e que sem dúvida há agenciadores "bandidos" nessa conexão B rasil-Europa, mas que os maiores constrangimentos são morais.

Ao contrário das décadas passadas, nesse início de século as travestis brasileiras na Europa já não ficam tanto nas ruas, sendo mais comum vê-las nessa condição em Portugal. Espanha e Portugal acabaram entrando na rota da prostituição travesti pelas facilidades migratórias: a não exigência de vistos e uma aduana menos rigorosa. Ainda assim, muitas se encontram em situação ilegal, porque entram, geralmente, com vistos de turistas, que expiram em três meses.

Dadas às dificuldades migratórias, países como Alemanha e Suíça não são tão procurados, ainda que haja travestis famosas trabalhando por lá e os programas custem mais caro. Mas o risco de uma deportação, além dos problemas com a polícia, são mais recorrentes na Europa central. 
As que se aventuram a partir sem o respaldo de "mães" e "financiadores" correm mais risco em qualquer país. Lá, como aqui, vale a rede de relações que se constrói e a qual se filia. Não se pode "descer pra avenida" sem ter um nome por trás, isto é, conhecer alguém minimamente influente no pedaço. ${ }^{30}$

É fato que algumas travestis fazem um patrimônio com os ganhos obtidos na Europa, se assim não fosse, o fluxo de travestis brasileiras para Velho Continente não se manteria. ${ }^{31} \mathrm{~A}$ maioria fica por 10/12 meses, outras se estabelecem. Às vezes se casam por lá, outras se mantêm na rota, indo e vindo, conforme a estação do ano ou a necessidade.

O sonho de partir é alimentado, sobretudo, pelas que voltam, pois são estas as que podem contar as histórias e aventuras vividas por lá; "dar close" passeando pelos pontos de prostituição em seus carros novos, com roupas de griffe e perfumes indisfarsavelmente caros, comprovando assim um duplo sucesso: 0 de ter competência para ganhar dinheiro e de ser suficientemente "bela" para consegui-lo a partir de seus atributos físicos. Os ganhos são investidos na sua transformação, preferindo o Brasil para isso.

$\mathrm{Na}$ Europa adquirem um outro traquejo: aprendem a falar um novo idioma, conhecem culturas diferentes, orgulhando-se de se aproximarem de um refinamento burguês, o que leva um conseqüente afastamento do gueto. A partir dessa experiência, ampliam seu leque de práticas eróticas e de classificação de clientes. Valorizam-se depois dessa estada européia, que tem seu

\footnotetext{
30 Uso o termo aqui no sentido empregado por Magnani como lugar dos colegas, dos chegados, onde há o sentimento de pertença e familiaridade, espacial e simbolicamente, pois se compartilham valores, bem como 0 uso de equipamentos urbanos disponibilizados naquele espaço. MAGNANI, J.G.C. De perto e de dentro: notas para uma etnografia urbana. Revista Brasileira de Ciências Sociais, vol. 17, no 49, junho de 2002, p.22.

${ }^{31}$ Os dados sobre esse fluxo são imprecisos, alguns informantes ligados a esse negócio calculam que cerca de 100 travestis brasileiras viajam para a Europa por ano. Entre estas, aquelas que já estiveram lá em outra ocasião.
} 
Na noite nem todos os gatos são pardos

aspecto glamouroso, mas também, como muitos testemunham, guarda momentos de solidão e dúvidas, comuns às experiências no exterior. Para algumas, a Europa significará um ponto de viragem, promovendo-as no mercado sexual brasileiro, não só pela sua passagem por lá, mas por possibilitar transformações radicais no corpo. Outras podem voltar empobrecidas e marcadas pelo fracasso financeiro, apontando para o insucesso como travesti, o que é extremamente doloroso. A Europa também pode abrir a possibilidade de saída da prostituição, ainda que as mantenha no comércio sexual, por exemplo, como "financiadoras".

Finalmente, o fato de ir para a Europa não tira a maioria das ruas nem proporciona altos ganhos por tempo prolongado. Muitas investirão em si, mas também ajudarão suas famílias, uma vez que essa é a forma que têm de resgatar o carinho ou conseguir aceitação dos seus.

As experiências se diferem, guardando em comum o fato de alimentar o sonho de ascensão social que, para muitas, está associado à possibilidade de serem tratadas com menos preconceito. Essa possibilidade, por sua vez, está relacionada não só com a idéia de que no Brasil o dinheiro compra cidadania, mas também à possibilidade se "passar por mulher", dado a investimentos sofisticados em seus corpos.

Enfim, no exterior ou no Brasil, a "avenida" ainda é o locus privilegiado de sociabilidade e de visibilidades das travestis, pois como analisa B enedetti:

É prioritariamente nestes espaços que (...) podem "verificar" se as estratégias de transformação de apresentação de si no feminino encontram reciprocidade, tanto por parte das outras travestis, como por parte dos outros habitantes deste universo social. ${ }^{32}$

\footnotetext{
32 BenedetTI, M. A batalha do corpo... Op. cit.
} 
A maior presença das travestis em espaços fora dos guetos (em revistas, programas televisivos e nas ruas), o crescimento do movimento social por direitos e dignidade (articulados pelo próprio grupo) e o surgimento e barateamento de tantas tecnologias estéticas está conformando uma nova geração de travestis. Talvez, em alguns anos, as ruas, do Brasil ou da Europa, não sejam mais o local privilegiado de construção da Pessoa travesti. Quem sabe nesse momento elas possam fazer da prostituição uma opção e não mais um destino.

A noite não é uma criança: reflexões finais

Conviver com travestis que se prostituem tem me mostrado que falar de "travesti" de uma forma generalizada e monolítica é perigosamente simplificador, na medida em que borra as singularidades de cada trajetória e as especificidades de cada entorno. Trabalhar no centro de São Paulo, na área industrial de São Carlos ou em um piso em Barcelona aponta para realidades distintas que conformam subjetividades específicas.

Em comum, as travestis guardam o desejo febril por um corpo transformado; um encantamento pela noite que pode se transformar, subitamente, em desprezo ou desejo de que tudo seja diferente - que outras possibilidades se desenhem, que um homem as queira de fato, de serem tratadas como "gente normal". "Porque a gente é normal. Ou você tá vendo algum bicho aqui?", pergunta Fabyanna Ferraz enquanto me olha profundamente.

A pesar dos perigos e da violência, enfatizo que o trabalho nas ruas é menos ameaçador do que a maioria das pessoas tende a acreditar, seja para as travestis, seja para as pesquisadoras. Não se trata de subestimar o campo, mas de desmistificá-lo.

A "noite", como uma temporalidade abstrata, na qual há espaço para a transgressão e sedução, é cheia de códigos e regras e as travestis aprendem logo que, nas muitas surpresas da noite, não há impunidade. No entanto, as dificuldades se acentuam ao 
Na noite nem todos os gatos são pardos

conviver com a dinâmica supostamente racionalizada e segura do dia, perío do em que, muitas vezes, "o risinho no canto da boca do intelectual macho (ou do gay respeitável)" encontra uma linha de comunicação com "a bala que fere o seio esquerdo" ${ }^{33}$ da travesti.

${ }^{33}$ SILVA, H. R. S. Travesti - a Invenção do Feminino - etnografia. Rio de J aneiro, Relume-Dumará, Iser, 1993, p.16. 